\title{
Deskripsi dan Potensi Jamur Makro Asal Hutan Adat Penembahen, Desa Juhar, Kabupaten Tanah Karo, Sumatra Utara
}

\section{Description and Potential of Macrofungi from Penembahen Customary Forest, Juhar Village, Tanah Karo District, North Sumatra}

\section{Sibero MT ${ }^{1}$, Putra IP ${ }^{2}$, Murwani $\mathbf{R}^{3}$}

${ }^{1}$ UPT Laboratorium Terpadu, Universitas Diponegoro, Semarang, Jawa Tengah, Indonesia

${ }^{2}$ Divisi Mikologi, Departemen Biologi, Institut Pertanian Bogor, Bogor, Jawa Barat, Indonesia

${ }^{3}$ Fakultas Peternakan dan Pertanian, Universitas Diponegoro, Semarang, Jawa Tengah, Indonesia

Sibero MT, Putra IP, Murwani R. 2021 - Deskripsi dan Potensi Jamur Asal Hutan Adat Penembahen, Desa Juhar, Kabupaten Tanah Karo, Sumatra Utara. Jurnal Mikologi Indonesia 5(1): 48-54. doi: 10.46638/jmi.v5i1.164.

\begin{abstract}
Abstrak
Jamur merupakan salah satu penyusun ekosistem hutan yang memiliki peran penting sebagai dekomposer. Namun kajian mengenai keragaman organisme ini di Indonesia masih sangat rendah, khususnya pada hutan adat. Penelitian ini dilakukan dengan tujuan untuk mendata, mendeskripsikan serta mengetahui potensi pemanfaatan jamur yang ditemukan di hutan adat Penembahen yang terdapat di Desa Juhar, Kabupaten Karo, Sumatra Utara. Identifikasi jamur dilakukan dengan mengamati karakteristik makroskopisnya. Penelitian ini berhasil mendeskripsikan 12 jenis jamur, 11 di antaranya termasuk filum Basidiomycota dan satu jenis termasuk filum Ascomycota. Kajian ini merupakan laporan pertama mengenai keberadaan jamur di lokasi penelitian.
\end{abstract}

Kata Kunci: Ascomycota - Basidiomycota - jamur - hutan adat - Juhar.

\section{Abstract}

Mushrooms have known as important decomposers in the forest ecosystem. Unfortunately, there is a limited report of its biodiversity in Indonesia, especially in the customary forest. This study was conducted to collect and describe several mushrooms in Penembahen, a customary forest for the Tarigan clan in Juhar Village, Karo Regency, North Sumatra. Fungal identification was conducted through morphological characterization. Our study successfully collected 12 mushrooms species which consisted of 11 species belonging to Basidiomycota and one species to Ascomycota. This study is the first report of mycobiota composition in the customary forest in the research site.

Keywords: Ascomycota - Basidiomycota - mushroom - customary forest - Juhar.

\section{Pendahuluan}

Sebagai negara tropis, Indonesia mendapatkan curah hujan serta paparan sinar matahari yang cukup tinggi sehingga mempengaruhi komposisi dan keragaman hayati di dalamnya (Brown, 2014). Penelitian terdahulu secara konsisten mengkaji kelimpahan organisme penyusun suatu ekosistem, bahkan beberapa tahun terakhir sudah banyak laporan mengenai penemuan jenis baru yang menambah daftar keragaman sumberdaya hayati di Indonesia (Kim et al., 2017; Retnowati, 2018; Asagabaldan et al., 2019; Sukarno et al., 2019; Larson et al., 2020). Berdasarkan laporan keragaman hayati tersebut, jamur merupakan salah satu anggota dunia jamur yang keragamannya belum banyak terungkap jika dibandingkan dengan total luas hutan yang dimiliki oleh Indonesia (Retnowati, 2018; Sukarno et al., 2019). Hingga 
tahun 2017, baru tercatat sebanyak 2273 jenis jamur (makro dan mikroskopik) di Indonesia. Angka tersebut hanya setara dengan $0.15 \%$ dari total estimasi jamur yang ada di seluruh dunia (LIPI, 2019).

Jamur merupakan organisme eukariotik, bersifat heterotrofik, hidup dengan cara saprofit, membentuk badan buah, dan ada beberapa yang hidup sebagai parasit maupun bersimbiosis mutualisme dengan inangnya (Tapwal et al., 2013). Organisme ini berperan sangat penting bagi hutan tropis dalam proses siklus nutrisi, membentuk jejaring lantai hutan, biokontrol alami, maupun sebagai agen bioremediasi pada lingkungan (Egli, 2011; Tapwal et al., 2013; Dworecka-kaszak, 2017). Beberapa studi melaporkan mengenai keragaman jamur yang hidup di taman nasional, tempat wisata, hingga yang terdapat di hutan kampus (Putra dkk., 2018; Putra dkk., 2019a; Putra dkk., 2019b; Tianara et al., 2020). Namun informasi mengenai keragaman jamur di hutan adat masih sangat jarang dilaporkan.

Hutan adat merupakan suatu kawasan hutan yang pengelolaan dan pemanfaatannya diatur oleh sistem adat yang berlaku di suatu wilayah (Sari \& Fu'adah, 2014; Subarudi, 2014). Salah satu hutan adat yang terdapat di Kabupaten Karo, Sumatera Utara adalah hutan adat Penembahen yang berlokasi di desa Juhar. Hutan ini dimanfaatkan oleh masyarakat yang bermarga Tarigan untuk berkebun, mengumpulkan buah, tanaman obat, sayur, hingga hewan liar untuk dikonsumsi sendiri maupun diperdagangkan. Aturan adat yang mengatur warga yang boleh masuk ke dalam hutan adat Penembahen membuat keragaman sumberdaya hayati di dalamnya, khususnya jamur, tidak pernah dikaji. Sehingga tujuan penelitian ini adalah untuk mendeskripsikan jamur yang ada di hutan adat Penembahen, desa Juhar, Kabupaten Karo, serta potensi pemanfaatannya. Informasi tersebut diharapkan bisa menambah data keragaman jamur di Indonesia serta dapat dijadikan sebagai acuan awal pemanfaatan jamur di lokasi penelitian.

\section{Metode Penelitian}

Penelitian dilakukan di Hutan Adat Penembahen, Desa Juhar, Kabupaten Karo Sumatera Utara pada bulan Maret 2020. Pengumpulan data jamur dilakukan dengan opportunistic sampling method merujuk pada penjelasan Prayudi et al. (2019). Identifikasi jamur dilakukan dengan menggunakan karakter makroskopik dengan bantuan loupe merujuk pada Putra dkk. (2018) dan Putra (2021) dengan modifikasi. Parameter identifikasi makroskopik meliputi cara tumbuh, bentuk tubuh buah, warna tudung (cap), bentuk atas cap, permukaan cap, tepian cap, margin cap, tingkat kebasahan, dan tipe himenofor (lamela, pori, gigi). Karakter lain yang diobservasi adalah bentuk stipe, warna stipe, permukaan stipe, posisi penempelan pada cap, tipe penempelan stipe pada substrat, partial veil dan universal veil, tekstur tubuh buah, serta informasi penggunaannya sebagai bahan pangan (edible atau nonedible) melalui wawancara dengan key person dan studi literatur untuk mendapatkan data mengenai pengetahuan lokal yang berhubungan dengan pemanfaatan jamur di kawasan tersebut. Sampel jamur diidentifikasi dengan menggunakan beberapa acuan identifikasi diantaranya Arora (1986), Largent (1973), Rokuya et al. (2011), dan Desjardin et al. (2015).

\section{Hasil}

Sebanyak 12 jamur berhasil diidentifikasi dan dipertelakan pada penelitian ini. Jamur yang ditemukan terbagi menjadi empat bangsa dan 11 suku (Tabel 1). Seluruh jamur tersebut terbagi ke dalam dua filum yakni Basidiomycota dan Ascomycota. Anggota Basidiomycota yang berhasil dikoleksi yaitu sebanyak tiga bangsa dan terdiri dari 10 suku dan sisanya adalah Ascomycota (Tabel 1). Masing-masing jamur memiliki karakteristik yang berbeda-beda. Berikut merupakan jenis yang diidentifikasi, karakter makroskopis, dan potensi pemanfaatannya. 
Tabel 1. Posisi taksonomi jamur asal hutan adat Penembahan, Desa Juhar, Kabupaten Karo

\begin{tabular}{|c|c|c|c|c|}
\hline Filum & Kelas & Bangsa & Suku & Jenis \\
\hline \multirow[t]{11}{*}{ Basidiomycota } & Agaricomycetes & Agaricales & Agaricaceae & Coprinus sp. \\
\hline & & & Lyophyllaceae & Termitomyces sp. \\
\hline & & & Mycenaceae & Mycena sp. \\
\hline & & & Omphalotaceae & Marasmiellus sp. \\
\hline & & & "Incertae sedis" & Collybia sp. \\
\hline & & & Psathyrellaceae & Coprinopsis sp. \\
\hline & & Auriculariales & Auriculariaceae & Auricularia sp. \\
\hline & & Polyporales & Fomitopsidaceae & Daedalea sp. \\
\hline & & & Polyporaceae & Ganoderma sp.1 \\
\hline & & & & Ganoderma sp. 2 \\
\hline & & & & Polyporus sp. \\
\hline Ascomycota & Sordariomycetes & Xylariales & Xylariaceae & Xylaria sp. \\
\hline
\end{tabular}

\section{Coprinus sp.}

Coprinus sp. tumbuh secara berkelompok dengan tubuh buah berdekatan dan muncul dari basal yang sama pada substrat berupa tanah (Gambar 1.A) dan bercampur dengan kayu yang melapuk (Gambar 1.B). Jamur ini memiliki bentuk tubuh buah berupa tudung (cap), berlamela, dan bertangkai (stipe). Tudung berwarna dominan coklat dengan warna lebih gelap pada bagian tepinya. Tudung berbentuk conical jika dilihat dari atas dan bentuk bagian bawah bundar (ovoid). Permukaan tudung halus (smooth), tepian bergerigi kecil, margin rata, dengan tepian tudung yang sedikit meluruh. Stipe berbentuk lurus sejajar (equal), berwarna krem, permukaan rata (smooth), menempel ke tudung pada posisi central, dan tipe penempelan pada substrat berupa basal tomentum. Tekstur tubuh buahnya cartilaginous tanpa bau yang khas.

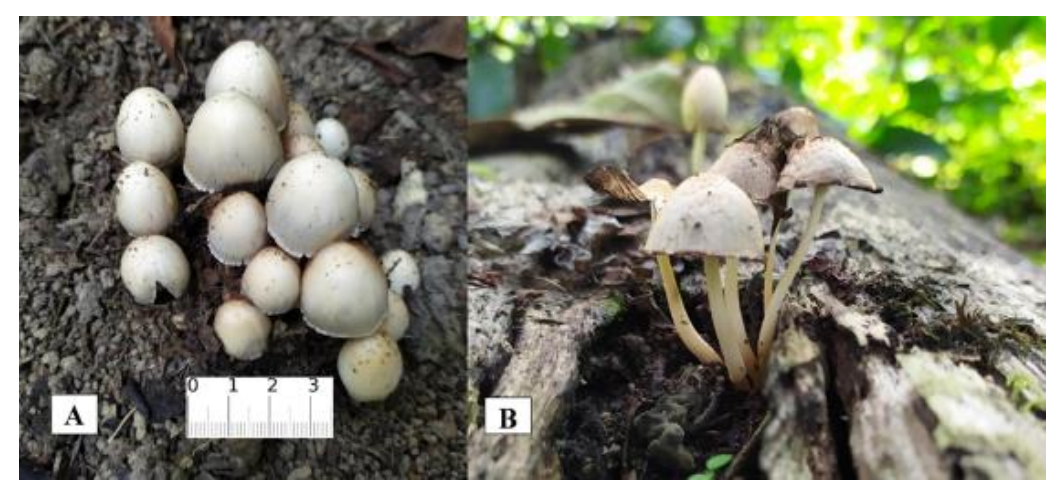

Gambar 1. Karakter makroskopis Coprinus sp. A. Tubuh buah tampak atas. B. Tubuh buah tampak samping

\section{Termitomyces sp.}

Termitomyces sp. tumbuh pada tanah ditutupi serasah dan berkelompok dalam jumlah yang sedikit. Jamur memiliki bentuk tubuh buah bertudung dengan himenofor berbentuk lamela dan tekstur tubuh buah yang berdaging. Tudung (cap) berwarna krem dengan bagian tengah menonjol (umbonate) (Gambar 2). Tudung Termitomyces sp. terlihat lebih kecil dibandingkan dengan jamur dari marga yang sama pada umumnya di Indonesia. Permukaan tudung halus (smooth) dengan tepian bergerigi dan diselingi dengan patahan yang lebar, margin incurved, dan tingkat kebasahan yang lembab (moist). Tangkai (stipe) berbentuk pseudorhiza, padat (solid), dan berwarna putih dengan panjang tidak diketahui karena memanjang ke dalam tanah (ditentukan oleh kedalaman sarang rayap). Tangkai menempel pada bagian tengah tudung dan pada arah berlawanan tertanam pada substrat (inserted). 
Jamur ini merupakan jamur edible yang pada sebagian besar wilayah di Indonesia dikenal dengan sebuatan jamur barat atau jamur rayap. Secara makroskopis, jamur ini memiliki kemiripan dengan Termitomyces fuliginosus namun perlu dilakukan oberservasi lebih lanjut untuk mengkonfirmasi hal tersebut.

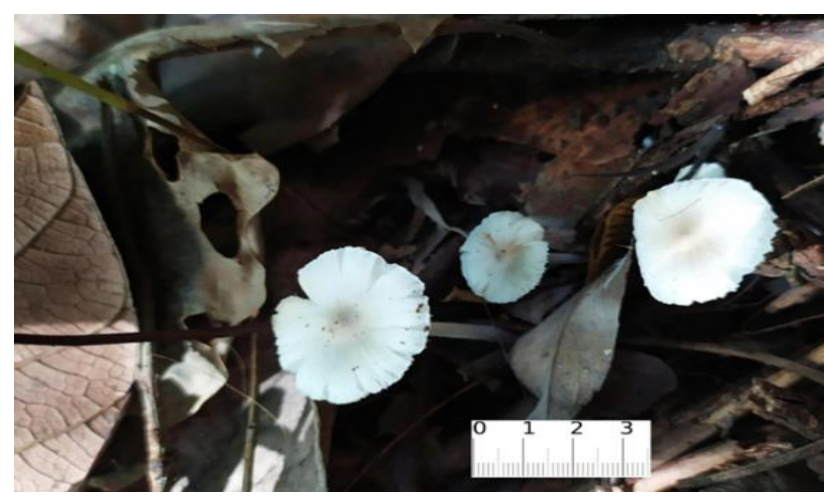

Gambar 2. Tubuh buah Termitomyces sp.

\section{Mycena sp.}

Mycena sp. tumbuh secara caespitose (berkelompok dan jarak antar tubuh buah sangat dekat, dilihat dari jarak stipe yang sangat dekat), di serasah yang bercampur tanah (Gambar 3). Tubuh buah jamur ini berupa tudung berlamela dengan stipe. Tudung berwarna putih hingga cream pada berbagai fase dengan bentuk atas convex dan bentuk bawah bundar. Permukaan tudung halus, tepian rata, dengan margin entire. Tingkat kebasahan jamur Mycena sp. yakni lembab (moist). Stipe berbentuk silindris berwarna coklat terang hingga putih gading, permukaan halus, posisi penempelan pada tudung central, tipe penempelan pada substrat yaitu basal. Tekstur tubuh buah lunak dan tanpa bau ataupun rasa yang khas.

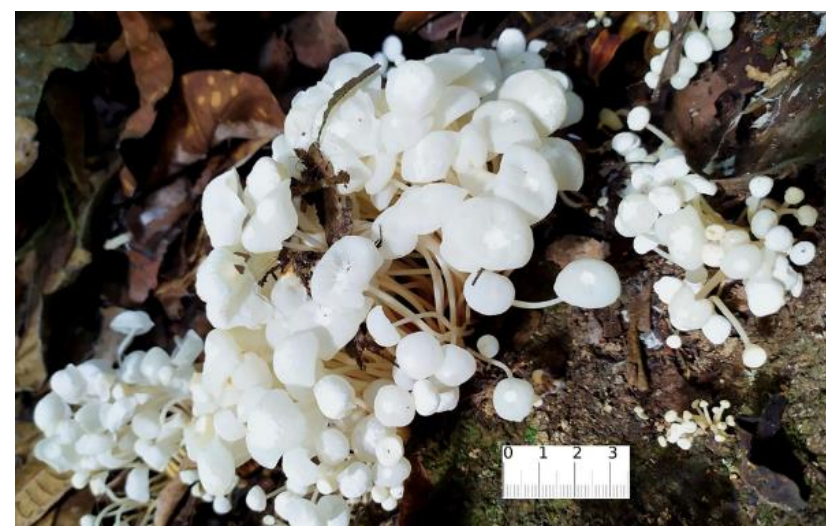

Gambar 3. Karakter makroskopis Mycena sp.

\section{Marasmiellus sp.}

Marasmiellus sp. tumbuh berkelompok dalam jumlah sedikit pada bongkahan kayu yang lapuk. Jamur ini memiliki tudung berlamela dengan stipe (Gambar 4). Tudung berwarna coklat hingga oranye, bentuk atas datar dengan bagian tengah sedikit menurun, permukaan atas bergaris melingkar dengan jarak teratur, bentuk bawah ovoid, tepian tudung yang rata dan margin entire. Jamur ini memiliki tingkat kebasahan yang lembap. Stipe berbentuk cylindric berwarna coklat muda, berongga, permukaan halus, menempel pada pileus pada bagian tengah, dan menempel pada substrat secara tertanam. Tekstur tubuh buah jamur ini berdaging dengan tangkai yang rapuh. 


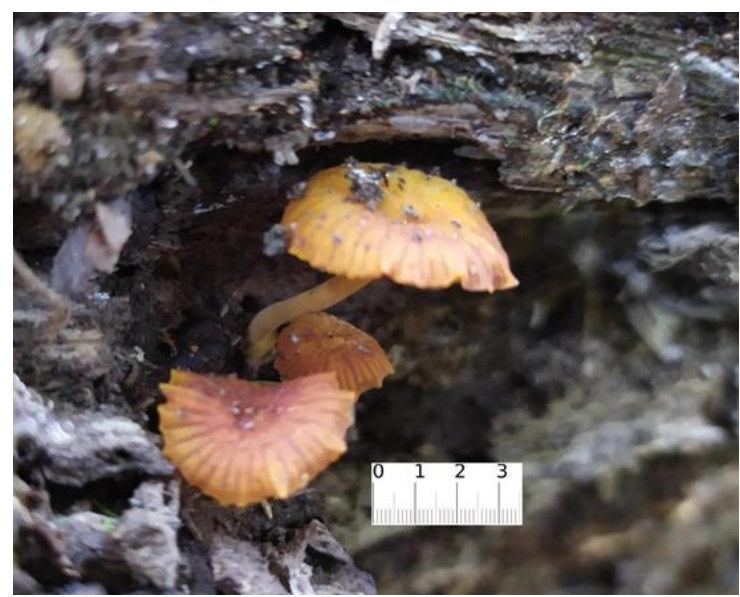

Gambar 4. Karakter makroskopis Marasmiellus sp.

\section{Collybia sp.}

Collybia sp. tumbuh secara berkelompok tetapi jarak antar tubuh buah tersebar (scattered) pada substrat berupa kayu lapuk (Gambar 5). Tudung (cap) berwarna krem hingga kecokelatan dan memiliki umbo pada bagian tengahnya. Tudung berbentuk lonceng (bell shape), bagian bawah tudung berbentuk bulat,permukaan halus, tepian tudung bergerigi (crenate), dan margin tudung miring paralel sedikit ke bawah (plane). Collybia memiliki tipe himenofor berupa lamela. Tangkai (stipe) berbentuk silindris, menempel di tengah tudung (central), dan berongga (hollow). Permukaan stipe halus, menempel pada substrat dengan tipe penempelan inserted. Tekstur tubuh buah jamur ini lunak berdaging dan tidak berbau.

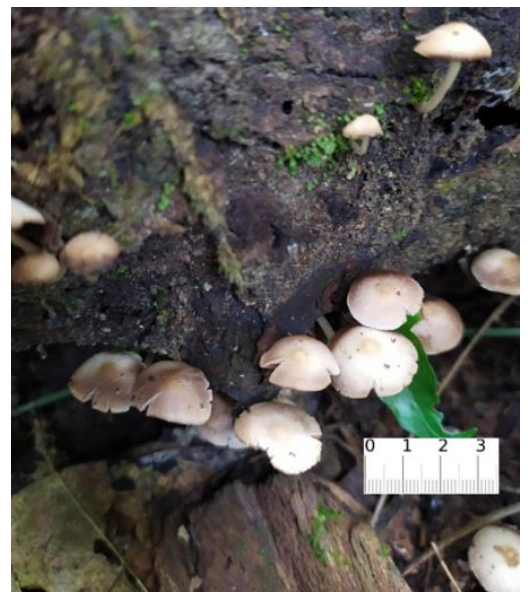

Gambar 5. Karakter makroskopis Collybia sp.

\section{Coprinopsis sp.}

Coprinopsis sp. tumbuh secara soliter pada substrat berupa tanah yang bercampur serasah (Gambar 6) dan bercampur dengan kayu yang melapuk (Gambar 1B). Jamur ini memiliki tudung (cap), himenofor berlamela, dan memiliki tangkai. Tudung berwarna coklat dengan bagian tepi menggulung ke arah atas dengan sedikit luruhan spora. Tudung berbentuk conical jika dilihat dari atas dan bentuk bagian bawah bundar (ovoid). Permukaan tudung halus (smooth) dengan ornamen berupa garis fibril dengan jarak yang teratur. Stipe berbentuk silinder yang sejajar pada semua bagian (equal), berwarna krem, permukaan sedikit bertepung, menempel ke tudung pada posisi central, dan tipe penempelan pada substrat berupa basal tomentum. Tekstur tubuh buah cartilaginous tanpa bau yang khas. 


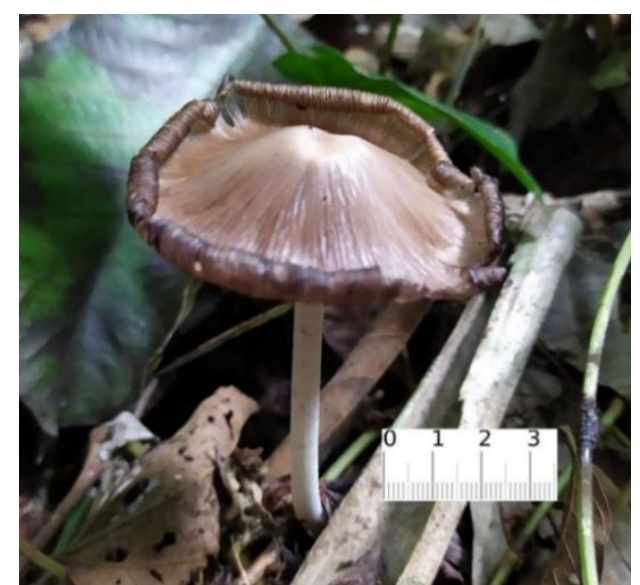

Gambar 6. Karakter makroskopis Coprinopsis sp.

\section{Auricularia sp.}

Tubuh buah jamur Auricularia sp. berbentuk jelly dan berwarna krem kekuningan (Gambar 7). Jamur ini tumbuh secara berkoloni pada batang pohon yang telah mati. jamur memiliki bentuk atas dan bawah tudung yang tidak beraturan, permukaan atas tudung memiliki tekstur relatif lebih halus dibandingkan dengan permukaan bawah. Individu Auricularia sp. memiliki tepian yang rata pada tubuh buahnya serta margin yang sedikit melengkung (Incurved). Jamur Auricularia sp. memiliki tipe himenofor pori dengan bentuk pori tidak beraturan. Auricularia sp. memiliki tekstur tubuh buah yang lunak.

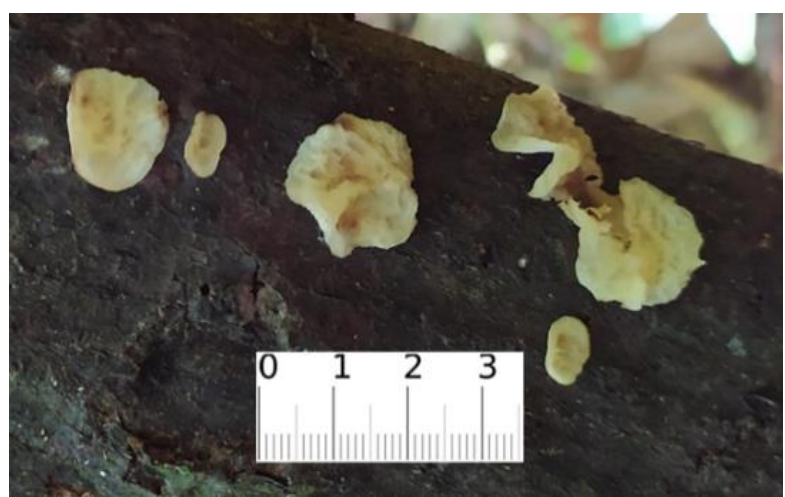

Gambar 7. Karakter makroskopis Auricularia sp.

\section{Daedalea sp.}

Daedalea sp. yang tumbuh secara soliter (Gambar 8), berbentuk bracket dengan himenofor berupa pori berupa labirin (tidak ditunjukkan). Tubuh buah berwarna coklat gelap dengan garis-garis horizontal melingkar. Tubuh buah rata (flat) pada bagian atas dan bentuk bawah spathulate. Permukaan tudung kasar, tepian rata (entire) dengan margin lurus (straight) hingga tertekuk sedikit melengkung (incurved). Tingkat kebasahan jamur Daedalea sp. kering. Himenofor pada Daedalea sp. bersifat non-detachable. Tubuh buah jamur Daedalea sp. melekat pada substrat secara sesil sehingga tidak memiliki stipe, flesh of stipe, partial veil dan universal veil. 


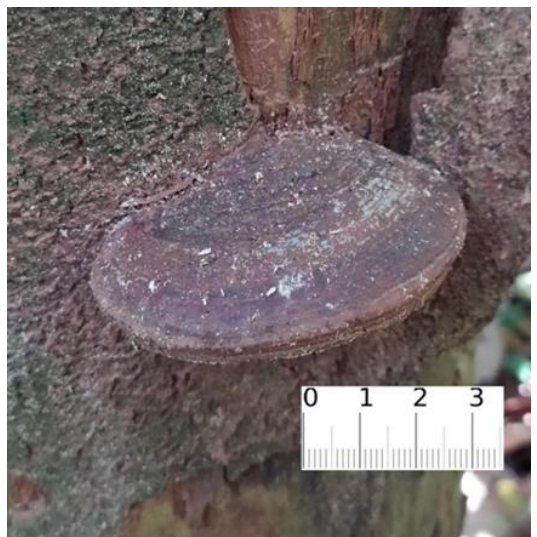

Gambar 8. Karakter makroskopis Daedalea sp.

\section{Ganoderma sp.1}

Ganoderma sp.1 tumbuh secara berkelompok dengan jumlah tubuh buah terbatas. Ganoderma sp. 1 memiliki tubuh buah berbentuk bracket shaped (Gambar 9). Tubuh buah dominan berwarna coklat dengan bagian berwarna hitam dan putih pada bagian tepinya. Tubuh buah jamur ini tidak mengalami perubahan warna ketika tua. Tubuh buah memiliki bentuk atas flat hingga bergelombang dan bentuk bawah menggembung tidak beraturan. Permukaan tudung kasar, tepian rata (entire) hingga bergelombang (undulate) dengan margin lurus (straight) hingga sedikit melengkung (incurved). Tingkat kebasahan jamur Ganoderma sp. 1 sangat kering. Tipe himenofor pada Ganoderma adalah pori yang bersifat nondetachable. Jamur Ganoderma sp.1 menempel langsung pada substrat atau sesil sehingga tidak memiliki stipe, flesh of stipe, partial veil dan universal veil.

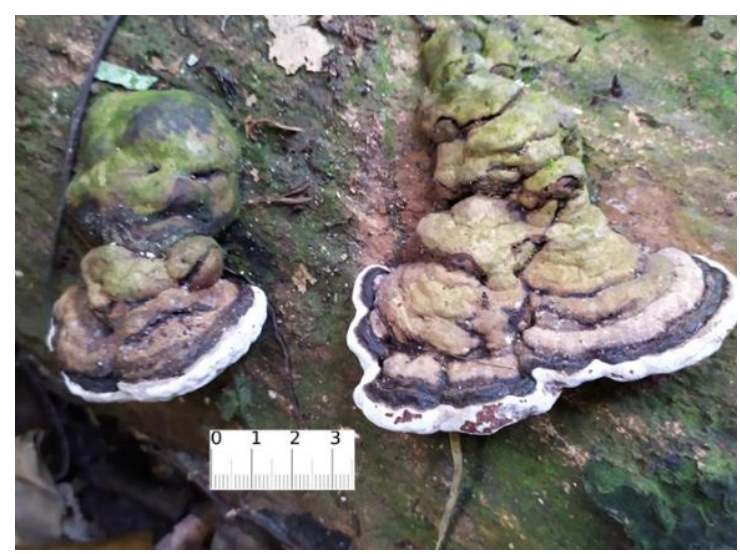

Gambar 9. Karakter makroskopis Ganoderma sp.1

\section{Ganoderma sp. 2}

Ganoderma sp.2 tumbuh secara soliter pada bongkahan kayu. Ganoderma sp. 2 memiliki tubuh buah dengan tipe bracket shaped (Gambar 10). Tubuh buah dominan berwarna coklat kehitaman yang cerah dengan bagian berwarna putih dan menebal pada bagian tepinya. Tubuh buah memiliki bentuk atas flat dan bentuk bawah menggembung tidak beraturan. Permukaan tudung licin, tepian rata (entire) dengan margin lurus (straight). Tingkat kebasahan jamur Ganoderma sp. 2 yaitu kering. Tipe himenofor pada Ganoderma adalah pori yang bersifat non-detachable. Ganoderma sp.2 menempel langsung pada substrat atau sesil sehingga tidak memiliki stipe, flesh of stipe, partial veil dan universal veil. 


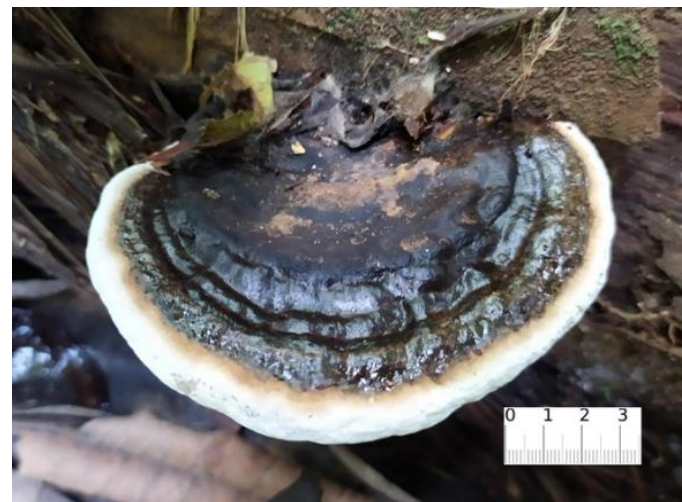

Gambar 10. Karakter makroskopis Ganoderma sp.2

\section{Polyporus sp.}

Polyporus sp. tumbuh pada kayu secara soliter pada kayu yang telah mati (Gambar 11). Jamur ini memiliki tudung dengan himenofor berupa pori, dan memiliki pseudostipe. Tudung berwarna krem dengan bentuk rata, dan memiliki tepian bergelombang dengan sedikit meruncing pada beberapa bagian. Jamur ini memiliki tubuh buah yang kering. Stipe berbentuk silindris berwarna coklat tua dan permukaan halus. Tangkai menempel pada pileus pada posisi central, dan menempel pada substrat secara basal tomentum, dan memiliki tubuh buah yang keras.

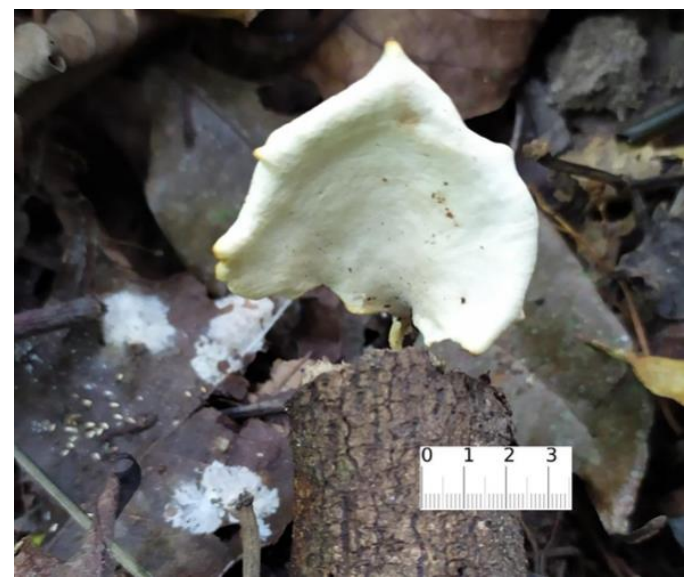

Gambar 11. Karakter makroskopis Polyporus sp.

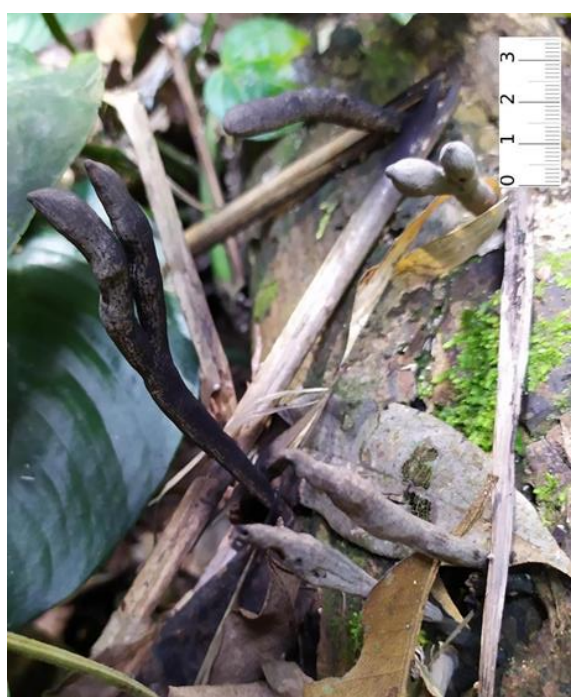

Gambar 12. Karakter makroskopis Xylaria sp. 


\section{Xylaria sp.}

Xylaria sp. tumbuh secara soliter hingga berkelompok dengan jarak antar tubuh buah berdekatan (gregarious) di pohon yang telah mati. Xylaria sp. berwarna putih keabuan pada fase muda dan hitam pada saat dewasa. Permukaan jamur ini tertutup bubuk halus dengan pangkal berwarna krem hingga kehitaman, tubuh buah Xylaria sp. berbentuk silindris, bercabang (dikotom) atau tidak (Gambar 12). Stroma keras dan tumbuh tegak pada substrat.

\section{Pembahasan}

Hasil identifikasi mengkonfirmasi keberadaan 11 jamur Basidiomycota di lokasi penelitian yaitu Coprinus sp., Termitomyces sp., Mycena sp., Marasmiellus sp., Collybia sp., Coprinopsis sp., Auricularia sp., Daedalea sp., Ganoderma sp.1, Ganoderma sp.2, dan Polyporus sp. Anggota Ascomycota yang berhasil dikoleksi adalah Xylaria sp.

Sebanyak 6 suku mewakili bangsa Agaricales pada penelitian ini. Jamur pertama adalah Coprinus sp. Jamur ini belum dimanfaatkan oleh masyarakat adat Penembahen. Beberapa jenis dari genus Coprinus dilaporkan dapat dikonsumsi seperti C. comatus, C. sterquilinus, dan $C$. truncorum yang berpotensi sebagai bahan pangan, antibakteri, dan inhibitor acetylcholinesterase (Yaseen et al., 2016; Pejin et al., 2019; Emsen \& Guven, 2020; Evita et al., 2020). Jamur berikutnya dari suku Lyophyllaceae adalah Termitomyces sp. Marga Termitomyces merupakan jamur liar konsumsi oleh masyarakat lokal di Indonesia (Putra dan Hafazallah, 2020). Beberapa kajian bioprospeksi cendawan Termitomyces mengungkap potensi bioteknologi jamur dalam bidang farmaseutika (Bhanja dan Rout, 2017; Hsieh dan Ju, 2018). Selain itu, hasil penelitian Zhao et al. (2017) menemukan bahwa polisakarida dari $T$. albuminosus memiliki aktivitas antioksidan, mampu menurunkan kandungan lemak serta melindungi hati dari kerusakan yang diakibatkan oleh lemak. Mycena sp. merupakan anggota dari Mycenaceae, pada penelitian ini Mycena sp. diperoleh di lokasi penelitian tumbuh di serasah di bawah pohon sehingga terlindung dari paparan sinar matahari. Masyarakat lokal tidak pernah memanfaatkan cendawan Mycena sp. meskipun sering ditemukan di kawasan hutan adat Penembahen karena terdapat pengetahuan lokal bahwa cendawan yang tidak berwarna mampu menyebabkan keracunan. Beberapa jenis dari Mycena diketahui memiliki potensi dalam bidang kesehatan. Liang et al. (2019) melaporkan potensi polisakarida dari $M$. dendrobii yang mampu menghambat radikal bebas dengan konsentrasi hambat ( $\left.\mathrm{IC}_{50}\right)$ sebesar $227 \mu \mathrm{g} / \mathrm{mL}$. Selain itu, Lohmann et al. (2018) menemukan dua senyawa baru, rosellin A dan rosellin $\mathrm{B}$, dari $M$. rosella yang berpotensi dalam menghambat berbagai mikroba patogen seperti Escherichia coli, Bacillus subtilis dan Staphylococcus capitis.

Suku Omphalotaceae diwakili oleh Marasmiellus sp. Jamur ini ditemukan di batang kayu lapuk dan berdasarkan informasi dari masyarakat lokal diketahui bahwa cendawan ini belum pernah ditemukan sebelumnya sehingga belum ada pengetahuan mengenai manfaat cendawan ini. Retnowati (2018) menyatakan bahwa Marasmiellus sp. merupakan salah satu agen dekomposer penting di suatu ekosistem. Beberapa peneliti lain melaporkan potensi dari jamur ini sebagai agen mikoremediasi untuk mendegradasi cemaran pewarna sintetik (Nemergut et al., 2000; Cantele et al., 2017). Jamur berikutnya adalah Collybia sp. Hasil koleksi informasi dari masyarakat adat menunjukkan bahwa jamur ini tidak pernah dikonsumsi maupun digunakan oleh warga sekitar untuk tujuan apa pun. Meski demikian, penelitian terdahulu melaporkan bahwa jenis dari marga Collybia yakni C. maculata mampu menghasilkan senyawa antivirus, sedangkan senyawa collybial yang diproduksi oleh $C$. confluens diketahui mampu menghambat pertumbuhan berbagai bakteri patogen (Leonhardt \& Anke, 1987; Simon et al., 1995). Jamur terakhir dari Ordo Agaricales adalah Coprinopsis sp. Hasil wawancara dengan warga lokal menunjukkan bahwa jamur ini belum pernah dimanfaatkan untuk tujuan apa pun. Meskipun demikian, hasil studi lain menunjukkan adanya potensi farmaseutika senyawa aktif dari marga Coprinopsis. Heleno et al., (2014) 
menyatakan bahwa $C$. atramentaria mengandung senyawa aktif seperti p-hydroxybenzoic (HA), p-coumaric (CoA) dan cinnamic (CA) yang berpotensi sebagai antioksidan serta antikanker. Selain itu, penelitian terbaru juga berhasil mengisolasi senyawa hitoyol A-B, bovistol $\mathrm{B}$, bovistol $\mathrm{D}$ dan strossmayerin yang memiliki berbagai aktivitas biologis penting bagi tubuh (Otaka et al., 2017; Banks et al., 2020).

Bangsa Auriculariales diwakili oleh Auricularia sp. pada penelitian ini. Jamur ini ditemukan tumbuh pada batang pohon cokelat (kakao) yang hampir mati. Masyarakat lokal pengguna hutan adat Penembahen menyatakan bahwa jamur ini tidak pernah digunakan sebagai bahan makanan maupun obat tradisional. Sebagai catatan pemanfaatannya, jenis dari marga Auricularia diketahui dapat dikonsumsi (edible) dengan potensi farmaseutika seperti antibakteri dan antioksidan adalah A. auricula, A. cornea, A. heimuer, dan A. polytricha (Abikote et al., 2019; Avci et al., 2016; Fang et al., 2019; Liu et al., 2019; Thongklang et al., 2020). Bangsa berikutnya adalah Polyporales yang diwakili oleh tiga suku dan empat jenis. Daedalea sp. merupakan satu-satunya jenis dari suku Fomitopsidaceae pada penelitian ini. Daedalea sp. tumbuh pada batang pohon yang sudah mati pada lokasi penelitian. Masyarakat lokal beranggapan bahwa jamur ini tidak dapat dikonsumsi. Penelitian terdahulu melaporkan bahwa $D$. dickinsii menghasilkan eksopolisakarida yang dapat menghambat radikal bebas (Mao et al., 2014). Sedangkan jenis lain seperti D. elegans dan D. gibbosa dilaporkan memiliki potensi sebagai antibakteri dan anti-inflamasi (Mensah-Agyei et al., 2020; Taofiq et al., 2016). Sebanyak dua jenis Ganoderma dipertelakan pada penelitian ini. Kedua jenis tersebut memiliki perbedaan pada bagian tepi dari tubuh buahnya. Kedua Ganoderma ditemukan pada batang kayu cokelat yang sudah mati. Masyarakat adat menyebutkan bahwa jamur ini menyebabkan kematian pada pohon cokelat yang ada di hutan adat Penembahen. Jamur ini sering dilaporkan sebagai fitopatogen pada berbagai tanaman seperti akasia, cokelat hingga sawit (Page et al., 2020; Hidayati \& Nurrohmah, 2015; Purnamasari et al., 2012). Jamur terakhir dari bangsa Polyporales adalah Polyporus sp. Jamur ini ditemukan di ujung potongan batang kayu di hutan adat Penembahen. Warga lokal menyatakan bahwa cendawan ini sangat jarang ditemui di hutan adat Penembahen. Hal ini mengindikasikan bahwa jamur ini belum begitu populer di kalangan masyarakat adat pada lokasi penelitian. Beberapa laporan menyatakan bahwa jamur ini sangat potensial sebagai penghasil metabolit dengan potensi farmaseutika seperti agen imunodulator, antiparasit, antitumor, antikanker, antivirus dan antiprotozoa (Abugri et al., 2019; Bandara et al., 2015; Glamočlija et al., 2018; Liu et al., 2016).

Satu-satunya anggota Ascomycota pada penelitian ini adalah Xylaria sp. Jamur ini ditemukan tumbuh pada batang pohon yang sudah lapuk. Berdasarkan hasil wawancara dengan masyarakat adat maka diketahui bahwa jamur ini tidak pernah digunakan untuk tujuan apa pun. Jamur dari marga ini diketahui tidak dapat dikonsumsi oleh manusia (nonedible). Namun beberapa laporan membuktikan bahwa jamur ini memiliki potensi farmaseutika (Noppawan et al., 2020; Wang et al., 2019a; Wanget al., 2019b). Selain metabolit sekunder, kajian dari Chang et al. (2018) menunjukkan bahwa eksopolisakarida dari jamur ini memiliki potensi sebagai antioksidan.

Berdasarkan hasil, dapat disimpulkan bahwa pada penelitian ini berhasil mengungkap dan mendeskripsikan 12 jamur yang terdapat di hutan adat Penembahen di Desa Juhar. Jamur yang ditemukan terdiri atas Coprinus sp., Termitomyces sp., Mycena sp., Marasmiellus sp., Collybia sp., Coprinopsis sp., Auricularia sp., Daedalea sp., Ganoderma sp.1, Ganoderma sp.2, Polyporus sp., dan Xylaria sp. Berdasarkan hasil wawancara dengan masyarakat pengguna hutan adat Penembahen diketahui bahwa tidak ada satupun jenis jamur yang diperoleh pernah digunakan sebagai bahan makanan maupun obat. 


\section{Ucapan Terima Kasih}

Penulis mengucapkan terima kasih atas bantuan Bapak Delta Tarigan, Pasta Tarigan, Dalan Mbelen Pinem, Edi Haris Pinem dan Ibu Legan Sembiring yang turut membantu dalam proses pengumpulan sampel jamur.

\section{Daftar Pustaka}

Abikoye, E. T., Oloke, J. K., Elemo, G., Okorie, P. C., Aier, S., Oluwawole, O. F. \& Barooah, M. (2019). Biosynthesis of silver nanoparticles in improved strain of Auricularia polytricha -an edible mushroom from Nigeria and its antimicrobial activities. Covenant Journal of Physical and Life Sciences (Special Edition), 7(1), 4755.

Abugri, D. A., Ayariga, J. A., Tiimob, B. J., Yedjou, C. G., Mrema, F., \& Witola, W. H. (2019). Medicinal mushrooms as novel sources for new antiparasitic drug development. In Medicinal Mushrooms. pp 251-273.

Arora, D. (1986). Mushrooms Demystified. USA, Teen Speed Press.

Asagabaldan, M. A., Bourgougnon, N., Bedoux, G., Kristiana, R., Ayuningrum, D., Widyananto, P. A., Muchlissin, S. I., Magueresse, A., Sabdono, A., Trianto, A., \& Radjasa, O. K. (2019). Some Cheilostomata (Bryozoa) from the Java Sea, central Indonesian Archipelago, with a description of Pleurocodonellina jeparaensis n. sp. (Smittinidae). Zootaxa, 4668(3), 329-342. doi: 10.11646/zootaxa.4668.3.2

Avci, E., Cagatay, G., Avci, G.A., Suicmez, M., \& Cevher, S.C. (2016). An edible mushroom with medicinal significance; Auricularia polytricha. Hittite J. Sci. Eng.,3(2), 111-116. doi: 10.17350/HJSE19030000040

Bandara, A.R., Rapior, S., Bhat, D. J., Kakumyan, P., Chamyuang, S., Xu, J., \& Hyde, K.D. (2015). Polyporus umbellatus, an edible-medicinal cultivated mushroom with multiple developed health-care products as food, medicine, and cosmetics: a review. Cryptogamie, Mycologie, 36(1), 3-42. doi: 10.7872/crym.v36.iss1.2015.3

Banks, A. M., Song, L., Challis, G. L., Bailey, A. M., \& Foster, G. D. (2020). Bovistol B, bovistol D and strossmayerin: Sesquiterpene metabolites from the culture filtrate of the basidiomycete Coprinopsis strossmayeri. PLoS ONE, 15(4), 1-9. doi: 10.1371/journal.pone.0229925

Bhanja, S. K., \& Rout, D. (2017). Structural analysis of two bioactive components of an edible mushroom, Termitomyces microcarpus. Nat. Prod. Comm.,12(12), 1917-1920. doi: $10.1177 \% 2 \mathrm{~F} 1934578 X 1701201226$

Brown, J. H. (2014). Why are there so many species in the tropics?.J. Biogeo.,41(1): 8-22.

Cantele, C., Vilasboa, J., dos Reis, E. E., Fontana, R. C., Camassola, M., \& Dillon, A. J. P. (2017). Synthetic dye decolorization by Marasmiellus palmivorus: Simultaneous cultivation and high laccase-crude broth treatment. Biocat. Agri. Biotech.,12, 314-322. doi: 10.1016/j.bcab.2017.10.025

Chang, C. K., Ho, W. J., Chang, S. L., Yeh, C. H., Liang, Z. C., Hsu, T. H., \& Hsieh, C. W. (2018). Fractionation, characterization and antioxidant activity of exopolysaccharide from fermentation broth of a Xylaria nigripes. Bioactive Carbo. Diet. Fibre.,16, 37-42. doi: 10.1016/j.bcdf.2018.02.005

Desjardin, D. E., Wood, M., \& Stevens, F. A. (2015). California mushrooms: The comprehensive identification guide.Portland, Oregon.

Dworecka-Kaszak, B. (2017). Cordyceps fungi as natural killers, new hopes for medicine and biological control factors. Ann. Parasitol., 60(3), 151-158.

Egli, S. (2011). Mycorrhizal mushroom diversity and productivity - an indicator of forest health? Ann. Forest Sci., 68, 81-88. doi: 10.1007/s13595-010-0009-3

Emsen, B., \& Guven, B. (2020). Activities of two edible macrofungi, Coprinus comatus and 
Leucoagaricus leucothites in human lymphocytes: cytogenetic and biochemical study. Plant Biosystems, 154(3), 361-368. doi: 10.1080/11263504.2019.1612479

Evita, E., Ratnaningtyas, N. I., \& Ryandini, D. (2020). Aktivitas antibakteri ekstrak tubuh buah Coprinus comatus terhadap Escherichiacoli dan Staphylococcus aureus. Bioeksakta, 2(1), 123-130.

Fang, M., Yao, F., Lu, L., Zhang, Y., Wang, P., Lu, J., Wang, W., \& Chen, X. (2019). Complete mitochondrial sequence of Auricularia heimuer, one of the most popular edible fungus in China. Mitochondrial DNA Part BResour., 4(2), 4029-4030. doi: $10.1080 / 23802359.2019 .1688717$

Glamočlija, J., Kostić, M., \& Soković, M. (2018). Antimicrobial and hepatoprotective activities of edible mushrooms. In Biology of Macrofungi pp. 81-113.

Heleno, S. A., Ferreira, I. C. F. R., Calhelha, R. C., Esteves, A. P., Martins, A., \& Queiroz, M. J. R. P. (2014). Cytotoxicity of Coprinopsis atramentaria extract, organic acids and their synthesized methylated and glucuronate derivatives. FoodRes. Inter., 55, 170-175. doi: 10.1016/j.foodres.2013.11.012

Hidayati, N., \& Nurrohmah, S. H. (2015). Karakteristik morfologi Ganoderma steyaertanum yang menyerang kebun benih Acacia mangium dan Acacia auriculiformis di Wonogiri, Jawa Tengah. Jurnal Pemuliaan Tanaman Hutan, 9(2), 117-130. doi: 10.20886/jpth.2015.9.2.117-130

Hsieh, H. M., \& Ju, Y. M. (2018). Medicinal components in Termitomyces mushrooms. Appl. Microbiol. Biotech., 102(12), 4987-4994. doi: 10.1007/s00253-018-8991-8

Kim, S., Heppner, J. B., Park, K., \& Kim, S. (2017). Eight new species of the genus Promalactis (Lepidoptera: Oecophoridae) from Indonesia, with a checklist of the genus. J. Nat. History, 51, 1-25. doi: 10.1080/00222933.2017.1353154

Largent, D.L. 1977. How to Identify Mushrooms to Genus I: Macroscopic Features. Eureka (CA), Mad River Press Inc.

Larson, H. K., Jaafar, Z., Hui, T. H., \& Peristiwady, T. (2020). Platygobiopsis adiatyae, a new species of deepwater gobiid from Indonesia (Teleostei, Gobiidae, Gobiinae). Raffles Bull. Zoology68, 14-18. doi: 10.26107/RBZ-2020-0002

Leonhardt, K., \& Anke, T. (1987). 6-Methylpurine, 6-Methyl-9-ß-D-ribofuranosylpurine, and 6-Hydroxymethyl-9-ß3-D-ribofuranosylpurine as antiviral metabolites of Collybia maculata (Basidiomycetes). Zeitschrift Für Naturforschung C,42(4), 420-424. doi: 10.1515/znc-1987-0415.

Liang, X., Gao, Y., Pan, Y., Zou, Y., He, M., He, C., Li, L., Yin, Z. \& Lv, C. (2019). Purification, chemical characterization and antioxidant activities of polysaccharides isolated from Mycena dendrobii. Carbo. Polymers, 203, 45-51. doi: 10.1016/j.carbpol.2018.09.046

[LIPI] Lembaga Ilmu Pengetahuan Indonesia. (2019). Status keanekaragaman hayati Indonesia: kekayaan jenis tumbuhan dan jamur Indonesia. Retnowati A, Rugayah, Rahajoe JS, Arifiani D. editor. Jakarta (ID): LIPI Press.

Liu, C., Chen, J., Chen, L., Huang, X., \& Cheung, P. C. K. (2016). Immunomodulatory activity of polysaccharide-protein complex from the mushroom sclerotia of Polyporus rhinocerus in murine macrophages. J. Agri. FoodChem., 64(16), 3206-3214. doi: 10.1021/acs.jafc.6b00932

Liu, X., Hou, R., Wang, D., Mai, M., Wu, X., Zheng, M., \& Fu, J. (2019). Comprehensive utilization of edible mushroom Auricularia auricula waste residue-extraction, physicochemical properties of melanin and its antioxidant activity. FoodSci. Nutri., 7(11), 3774-3783. doi: 10.1002\%2Ffsn3.1239

Lohmann, J. S., von Nussbaum, M., Brandt, W., Mülbradt, J., Steglich, W., \& Spiteller, P. (2018). Rosellin A and B, two red diketopiperazine alkaloids from the mushroom 
Mycena rosella. Tetrahedron, 74(38), 5113-5118. doi: 10.1016/j.tet.2018.06.049

Mao, D. Bin, Shi, C. W., Wu, J. Y., \& Xu, C. P. (2014). Optimization of exopolysaccharide production in submerged culture of Daedalea dickinsii and its antioxidant activity. Bioproc. Biosys. Eng., 37(7), 1401-1409. doi: 10.1007/s00449-013-1111-3

Mensah-Agyei, G.O., Ayeni, K.I., \& Ezeamagu, C. O. (2020). GC-MS analysis of bioactive compounds and evaluation of antimicrobial activity of the extracts of Daedalea elegans: A Nigerian mushroom. African Journal of Microbiology Research, 14(6), 204-210.

Nemergut, D. R., Wunch, K. G., Johnson, R. M., \& Bennett, J. W. (2000). Benzo[a]pyrene removal by Marasmiellus troyanus in soil microcosms. J. Indus. Microbio. Biotech., 25(2), 116-119.

Noppawan, S., Mongkolthanaruk, W., Suwannasai, N., Senawong, T., Moontragoon, P., Boonmak, J., Youngme, S., \& McCloskey, S. (2020). Chemical constituents and cytotoxic activity from the wood-decaying fungus Xylaria sp. SWUF08-37. Nat. Prod. Res., 34(4), 464-473. doi: 10.1080/14786419.2018.1488709

Otaka, J., Hashizume, D., Masumoto, Y., Muranaka, A., Uchiyama, M., Koshino, H., Futamura, Y., \& Osada, H. (2017). Hitoyol A and B, two norsesquiterpenoids from the basidiomycete Coprinopsis cinerea. OrganicLet., 19(15), 4030-4033. doi: 10.1021/acs.orglett.7b01784

Page, D. E., Glen, M., Puspitasari, D., Prihatini, I., Gafur, A., \& Mohammed, C. L. (2020). Acacia plantations in Indonesia facilitate clonal spread of the root pathogen Ganoderma philippii. Plant Pathology, 69(4), 685-697. doi: 10.1111/ppa.13153

Pejin, B., Tešanović, K., Jakovljević, D., Kaišarević, S., Šibul, F., Rašeta, M., \& Karaman, M. (2019). The polysaccharide extracts from the fungi Coprinus comatus and Coprinellus truncorum do exhibit AChE inhibitory activity. Nat. Prod. Res., 33(5), 750754. doi: 10.1080/14786419.2017.1405417

Prayudi, D. P., Kurniawati, J., Mutiarani, Y. P., Salim, I., \& Aminatun, T. (2019). Considering sampling methods for macrofungi exploration in turgo tropical forest ecosystem. Journal of Tropical Biodiversity and Biotechnology, 4(1), 1. doi: $10.22146 /$ jtbb.38381.

Purnamasari, M., Prihatna, C., Gunawan, A. W., \& Suwanto, A. (2012). Isolasi dan identifikasi secara molekuler Ganoderma spp. yang berasosiasi dengan penyakit busuk pangkal batang di kelapa sawit. Jurnal Fitopatologi Indonesia, 8(1), 9-15. doi: 10.14692/jfi.8.1.9

Putra, I. P., \& Amelya, M. P. (2019a). Notes of some macroscopic fungi at IPB University Campus Forest: diversity and potency. Biota, 12(2), 57-71. doi: 10.20414/jb.v12i2.192

Putra, I. P., Nasrullah, M. A., \& Dinindaputri, T. A. (2019b). Study on diversity and potency of some macro mushroom at Gunung Gede National Park. Buletin Plasma Nutfah, 25(2), 1-14. doi: 10.21082/blpn.v25n2.2019.p1-14

Putra, I. P., Sitompul, R., \& Chalisya, N. (2018). Ragam dan potensi jamur makro asal taman wisata Mekarsari Jawa Barat. Al-Kauniyah: J. Biol., 11(2), 133-150. doi: 10.15408/kauniyah.v11i2.6729

Putra, I.P. (2021). Panduan karakterisasi jamur makroskopik di Indonesia: Bagian 1 Deskripsi ciri makroskopis. Jurnal Penelitian Kehutanan Wallacea, 10(1), 25-37. doi: 10.18330/jwallacea.2021.vol10iss1pp25-37.

Putra, I.P., \& Hafazallah, K. (2020). Catatan Komunitas Pemburu Jamur Indonesia: Kolaborasi Lintas Profesi dan Generasi Mengenai Etnomikologi Jamur-Jamur Indonesia. Sukabumi: Haura Publishing.

Retnowati, A. (2018). The species of Marasmiellus (Agaricales: Omphalotaceae) from Java and Bali. Gardens' Bull. Singapore, 70(1), 191-258. doi: 10.26492/gbs70(1).2018-17

Rokuya, I., Yoshio, O., \& Tsugia, H. (2011). Fungi of Japan. Japan, Yama-Kei Publishers. 
Sari, D. M., \& Fu'adah, A. (2014). Peran pemerintah daerah terhadap perlindungan hutan adat pasca putusan mahkamah konstitusi nomor 35/PUU-X/2012*. J. Penel. Hukum. $1(1), 53-61$.

Simon, B., Anke, T., Anders, U., Neuhaus, M., \& Hansske, F. (1995). Collybial, a new antibiotic sesquiterpenoid from Collybia confluens (Basidiomycetes). Zeitschrift Für Naturforschung C. J. Biosci, 50(3-4), 173-180. doi: 10.1515/znc-1995-3-403

Subarudi, S. (2014). Kebijakan pengelolaan hutan adat pasca putusan Mahkamah Konstitusi No. 35/PUU-X/2012: suatu tinjauan kristis. J. Anal. Kebijakan Kehutanan, 11(3): 207224.

Sukarno, N., Listiyowati, S., Rahayu, N., \& Nara, K. (2019). Elaphomyces tropicalis sp. nov.: A new ectomycorrhizal fungus associated with dipterocarps from tropical Indonesia. Mycoscience, 60(2), 83-88. doi: 10.1016/j.myc.2018.12.004

Taofiq, O., Martins, A., Barreiro, M. F., \& Ferreira, I. C. F. R. (2016). Anti-inflammatory potential of mushroom extracts and isolated metabolites. Trends Food Sci. Tech.,50, 193-210. doi: 10.1016/j.tifs.2016.02.005

Tapwal, A., Kumar, R., \& Pandey, S. (2013). Diversity and frequency of macrofungi associated with wet ever green tropical forest in Assam, India. Biodiversitas, 14(2), 7378. doi: 10.13057/biodiv/d140204

Thongklang, N., Keokanngeun, L., Taliam, W., \& Hyde, K. D. (2020). Cultivation of a wild strain of Auricularia cornea from Thailand. Curr. Res. Env. App. Myco., 10(1), 120130.

Tianara, A., Susan, D., \& Sjamsuridzal, W. (2020). New recorded species of polypore for Indonesia found in Universitas Indonesia Depok Campus. IOPConf. Ser.: 4EES.,457, 012010. doi: 10.1088/1755-1315/457/1/012010

Wang, W. X., Cheng, G. G., Li, Z. H., Ai, H. L., He, J., Li, J., Feng, T., \& Liu, J. K. (2019a). Curtachalasins, immune suppressive agents from the endophytic fungus: Xylaria cf. curta. Organic Biomol. Chem., 17(34), 7985-7994.

Wang, W. X., Feng, T., Li, Z. H., Li, J., Ai, H. L., \& Liu, J. K. (2019b). Cytochalasins D1 and $\mathrm{C}$, unique cytochalasans from endophytic fungus Xylaria cf. curta. Tetrahedron Let., 60(34): 150952. doi: 10.1016/j.tetlet.2019.150952

Yaseen, T., Khan, M., Shakeel, M., \& Ara, H. (2016). Morphological study of edible and non- edible mushrooms, district Swabi, Khyber Pakhtunkhwa, Pakistan. Pure App. Biol., 5(4), 889-894. doi: 10.19045/BSPAB.2016.50112

Zhao, H., Li, J., Zhang, J., Wang, X., Liu, M., Zhang, C., \& Jia, L. (2017). Hepatoprotective and in vitro antioxidant effects of native depolymerized-exopolysaccharides derived from Termitomyces albuminosus. Sci. Rep., 3910. doi: 10.1038/s41598-017-04171-0. 